\title{
When the Analogy Breaks
}

\section{Historical References in Flemish News Media at the Onset of the covID-19 Pandemic}

\author{
Bram De Ridder \\ KU Leuven, Leuven, Belgium; \\ Corvus Historical Consultancy, Leuven, Belgium \\ bram.deridder@kuleuven.be
}

Received April 2020 | Accepted April 2020 | Published online April 21, 2020

\begin{abstract}
Between 1 January and 13 March 2020, Flemish media gradually increased their attention to the new Corona virus and the associated CoviD-19 disease. This coverage included a lot of attention to the past, as history offered many opportunities for explaining the emerging crisis. In order to better understand this relation between history and news, this article analyses the virus-related coverage of three Flemish media outlets and the historical references included in it. The research shows that, in some media, history was included in up to $65 \%$ of the news articles concerning Corona, with the SARS-epidemic of 2002-2003 being the dominant point of reference. However, as time progressed it became obvious that this reliance on sARs led to an understandable, yet highly unfortunate mistake, forcing the three media to diversify their historical references. As such, the consequences of the recent comparisons between SARs and COVID-19 offer a warning for using the past in the next stages of the crisis.
\end{abstract}

\section{Keywords}

COVID-19 - media - news - pandemic - SARS - Flanders 
The recent CoviD-19 pandemic has already received an extreme amount of attention in national and international media. ${ }^{1}$ From the start, history has provided an important reference point for this coverage, as articles, interviews, columns, and op-eds have relied on several historical cases to discuss current events. Epidemics such as the 14th century Black Death, the 1918-1919 Spanish Flu, or the 2002-2003 SARS outbreak have been frequently mentioned, as has the financial crisis of 2008. Some commentators have used these and other historical examples to contextualize the on-going outbreak, whereas others have used them to make predictions about the future. Many other types of references could be noticed as well. ${ }^{2}$ So, whatever the reason and the specific application of history, the past mattered a lot in the early CoviD-19 media coverage.

Analysing how this relation between history and news works, is an important topic for the field of applied history. ${ }^{3}$ This is even more so when history has the potential to influence how an on-going crisis is perceived, and, potentially, how it is handled by policymakers. ${ }^{4}$ Therefore, this article discusses how three major news outlets in Flanders have used history during the early days

1 This research is part of the 'Corvus' project of the KU Leuven (www.corvushc.be), which was generously funded by the Research Foundation Flanders-FWo. I would like to thank Prof. Dr. Violet Soen and the anonymous reviewers for their suggestions, Sarang A. Shah for his English language review, and the editors and publisher of this journal for their support.

2 Internationally speaking, the following articles merely illustrate the various historical arguments printed: L. Spinney, “Closed borders and 'black weddings': what the 1918 flu teaches us about coronavirus." The Guardian, March 11, 2020, https://www.theguardian.com/world/ 2020/mar/11/closed-borders-and-black-weddings-what-the-1918-flu-teaches-us-about-coron avirus; J. Brown, "The Coronavirus is no 1918 pandemic." The Atlantic, March 3, 2020, https:// www.theatlantic.com/ideas/archive/202o/o3/were-not-facing-second-spanish-flu/6o7354/; G. Brockel, "Trump is ignoring the lessons of the 1918 flu pandemic that killed millions, historian says." The Washington Post, February 29, 2020, https://www.washingtonpost.com/ history/2020/o2/29/1918-flu-coronavirus-trump/; M. Vargas Llosa, “¿Regreso al Medioevo?” El Pais, March 15, 2020, https://elpais.com/elpais/2020/o3/13/opinion/1584090161_414543.html; P.-C. Hautcoeur, "La grippe espagnole, un secret trop bien gardé." Le Monde, March 4, 2020, https://www.lemonde.fr/idees/article/2020/o3/o4/la-grippe-espagnole-un-secret-trop-biengarde_6o31737_3232.html; S. Schmitt and A.L. Scholz, “"Die Mutter aller Pandemien.” " Die Zeit, January 29, 2020, https://www.zeit.de/2020/o6/spanische-grippe-virus-seuche-pandemie.

3 This approach should be considered different from the 'Media History' that focusses on communicating information about the past to a broader audience, and from the 'Media History' that writes histories of the media. For the former, see for example B. Dooley, "Media and History." In International Encyclopedia of the Social \& Behavioral Sciences, 2nd edition, ed. J.D. Wright (Oxford: Elsevier, 2015), 11-18. For the latter, see for example the journal Media History, published by Taylor \& Francis.

4 In this regard, see for example A.B.R. Elliott, Medievalism, Politics and Mass Media. Appropriating the Middle Ages in the Twenty-First Century (Woodbridge: Boydell \& Brewer, 2017). 
of the Corona crisis. A first goal is to provide some basic information on when and how often the past has influenced Flemish news at the beginning of the outbreak. The second is to determine which historical cases have proved to be dominant in this coverage. Third and last, it is the ambition to show how these cases have been used to describe or discuss covid-19-related events. As this article will show, Flemish media outlets have relied quite heavily on history-influenced reasoning, with the 2002-2003 SARS epidemic serving as a key analogy.

This analysis has a dual intended audience. On the one hand, the data will be useful to applied historians interested in a case-study of the historical references used by the media in times of crisis. On the other hand, the conclusions can also serve journalists, news editors, and policymakers handling the current pandemic, as the article demonstrates that even casual references to the past can distort one's view of the present. Specifically for Flanders, there are strong indications that relying on historical analogies provided a false sense of security at the beginning of the Corona outbreak, whereas during subsequent events the past was mainly used as a potpourri of different relevant and irrelevant references. There might have been good reasons to compare the early stages of the COVID-19 outbreak with the 2002-2003 SARS epidemic, but it was a mistake to continue using this analogy as a reassurance for the future. Although this conclusion necessarily relies on the hindsight we have today, the article still uncovers some basic anomalies in public historical reasoning, which might be present in other (international) media as well. ${ }^{5}$

Methodology

For this analysis, the Corona-related coverage of three major Flemish news outlets was observed from 1 January 2020 to 13 March 2020: the national medium VRT NWs, and the newspapers De Standaard and De Morgen. The first outlet, VRT NWs, is the main news channel of the Flemish national broadcasting company. It is government funded, but its editors operate independently. VRT NWS is the main provider of audio-visual news in Dutch-speaking Belgium, with only one private company offering a comparable service. The VRT Nws website, which provided the data for this study, offers text articles on

5 See in this regard also the op-ed by G. Lachenal and G. Thomas, "CoviD-19: When history has no lessons." History Workshop, March 30, 2020, http://www.historyworkshop.org.uk/covid-19 -when-history-has-no-lessons/. 
all contemporary news, but also aims to provide more in depth-analyses as well as general background information. In addition to this content, the website also places a lot of stress on historical remembrance, with entire sections of its homepage dedicated to, for example, the events of World War I and II. Crucially, VRT NWs targets a very broad audience with easily digestible texts. ${ }^{6}$

Secondly, De Standaard is one of two publications that are considered 'highend' newspapers in Flanders. The newspaper stems from a Catholic background, although this affiliation has lost much of its significance in a secularizing society. It considers itself to be a centrist publication, tending to a higher-educated and somewhat conservative audience. It has both an online and a paper presence in Flanders. De Standaard is privately owned by the Flemish media concern Mediahuis. ${ }^{7}$ Finally, De Morgen is considered the centre-left counterpart to De Standaard. The newspaper is historically situated in a socialist background and maintains a 'progressive' editorial position. Its audience is generally younger and more left-leaning than that of De Standaard, but it is likewise higher-educated. Like its counterpart, De Morgen has both an online and a paper presence, and is owned by the private concern D PG Media. ${ }^{8}$ Jointly, VRT Nws, De Standaard and De Morgen cater to a large part of the (higher-educated) Flemish population. ${ }^{9}$

Only the online text publications of these three outlets were monitored for this study. Their digital archives were searched for the aforementioned period of 1 January 2020 to 13 March 2020, with the term 'virus' being the only search query used. No specific historical search terms were applied (e.g. 'Spanish Flu' or 'plague'). This implies that articles about, for example, PC viruses or the seasonal flu also appeared in the results, but not to a degree to distort the overall picture. The results of this basic search were subsequently checked for historical references, after which the specific historical elements cited were identified. At this stage, a small number of articles were excluded, as the analysis focused on journalistic articles, op-eds and, columns. The deselected items were the

6 www.vrt.be/vrtnws/nl/.

7 www.standaard.be/.

8 www.demorgen.be/.

9 Belgium has a total population of about 11,64 million, Flanders of nearly 6,6 million. The Centrum voor Informatie over de Media or CIM has calculated that last year De Standaard reached about 1,863 million people across all its platforms; for De Morgen that number was 1,391 million. Similar numbers are lacking for VRT NWS, but on the 2018 Belgian local election day, its website received 1,19o million individual visitors: see https://www.vrt.be/nl/over-de-vrt/ nieuws/2018/10/15/vlamingen-vonden-massaal-de-weg-naar-de-vrt-voor-informatie-over/. For full details for De Standaard and De Morgen, see the cIM-website, which collects annual data on the reach and audiences of all Belgian media: www.cim.be. 
fragmentary 'live updates/live blog' each outlet provided, satirical pieces, cultural advice pieces, and items that contained no text but only linked to audioor video-files. It should also be noted that 'historical reference' is here defined in a very broad sense, namely as 'something from the past', which includes the very recent past. Finally, purely biological references to viruses were left out. So if an article mentioned that the new virus is similar to the SARS or MERS viruses, this did not qualify as a historical reference because of the lack of temporal connotation. However, if that article mentioned that the recent outbreak is similar to earlier epidemics of the SARS- or MERS-related diseases, this did qualify because it refers to a specific past event. ${ }^{10}$

\section{The General Trajectory of coviD-19 Coverage}

The period from 1 January to 13 March can be divided into three specific subperiods, based on important evolutions in how Flemish society perceived the new Corona virus. For the most of January, Flemish media paid relatively little attention to the virus, with those articles logically focussing on developments in China. Commentators and journalists expressed little real concern during this period. In the course of February this attitude changed, with worries growing steadily, although the three media outlets (and the people they interviewed or cited) mostly struck a reassuring tone. Still, the growing concern led to a significant increase in the amount of virus-related articles $(+269 \%)$ between January and February, especially when by the end of February the stock markets started to slump. Finally, in the first two weeks of March it became clear that the virus would seriously affect Flanders as well, leading to a further increase in coverage ( $+147 \%$ compared to February, for these two weeks alone). The last week of the monitored period proved especially decisive, as the Belgian and Flemish governments took the first serious virus-related measures, leading newspapers and other media to provide quick online information about the policy's content and impact. Therefore, 13 March, the last day before the Belgian "lockdown", is also the last day included in the research.

Interestingly, the number of articles containing historical references followed an inverse trajectory. In absolute numbers the references to the past increased from January to February, and the first two weeks of March also showed a per-day growth, but as a percentage of the total coverage history

10 The full 'raw data' set and the 'quantitative data' set are available on the Corvus website, www.corvushc.be/reports. 
TABLE 1 Number of articles containing 'virus'

\begin{tabular}{lcccr}
\hline & $\mathbf{1} / \mathbf{1}-\mathbf{3 1} / \mathbf{1}$ & $\mathbf{1 / 2}-\mathbf{2 9} / \mathbf{2}$ & $\mathbf{1} / \mathbf{3}^{-\mathbf{1 3}} \mathbf{3}$ & Total \\
\hline VRT NWS & 59 & $\mathbf{1 7 8}$ & 303 & 540 \\
De Standaard & 70 & 192 & 246 & 508 \\
De Morgen & 35 & 72 & 103 & 210 \\
Total & 164 & 442 & 652 & 1258 \\
\hline
\end{tabular}

clearly lost importance. Whereas in January nearly $41 \%$ of the Corona-related articles contained one or more historical references, in February this dropped to around $27 \%$. In the first two weeks of March this figure continued to fall to $16,4 \%$, with the steepest drop noted for VRT NWS-from almost $29 \%$ in January to $8,6 \%$ in March.

The reason for this decrease is the same for all three media outlets. In January the virus was still something unknown, so journalists and commentators compared it to prior epidemics to explain it to their readers. Two things broke this tendency. First and foremost, in early February the death toll of the new disease surpassed that of the 2002-2003 SARS epidemic, almost immediately rendering this widely-cited historical outbreak useless for explanations and predictions. Secondly, as the spread of the virus started to pick up pace, so did the events related to it, forcing the three media outlets to favour articles that described what was happening over articles that explained what was happening. Put differently, current affairs were considered more important than (historically) contextualized news. Importantly, throughout this period the new disease was rarely described as a 'unique' historical event - it were mainly the economic consequences that were considered to be unprecedented (e.g. 'the largest oneday losses ever' on stock markets).

Also important to note are the differences between the three outlets. Although VRT NWs has extensive historical sections on its homepage, this outlet had the lowest overall percentage of pieces referring to the past-only $13 \%$. A possible explanation for this is that VRT NWs had to play its role as a public broadcaster, which led it to focus on providing the most accurate and up-todate information to Flemish citizens. Moreover, given its broader audience VRT NWs probably refrained from including too many historical analogies, as these are often harder to digest than basic facts. In this regard De Standaard occupied a middle position, with about $26 \%$ of its Corona-related articles mentioning the past - the newspaper clearly paid more attention to historical background and analysis than vRT Nws. De Morgen, however, was the medium that cited 
TABLE 2 Articles including a historical reference, as a percentage of the total number of articles containing 'virus' per period and per outlet

\begin{tabular}{lrrrc}
\hline & $\mathbf{1} / \mathbf{1}-\mathbf{3 1} / \mathbf{1}$ & $\mathbf{1} / \mathbf{2}-\mathbf{2 9} / \mathbf{2}$ & $\mathbf{1} / \mathbf{3}-\mathbf{1 3} / \mathbf{3}$ & Total \\
\hline VRT NWS & $\mathbf{2 8 , 8 1} \%$ & $\mathbf{1 6 , 9 2} \%$ & $8,58 \%$ & $\mathbf{1 3 , 3} \%$ \\
De Standaard & $38,57 \%$ & $29,68 \%$ & $\mathbf{1 9 , 5 1} \%$ & $25,98 \%$ \\
De Morgen & $65,71 \%$ & $47,22 \%$ & $32,03 \%$ & $42,85 \%$ \\
Total & $40,85 \%$ & $27,14 \%$ & $16,41 \%$ & $23,37 \%$ \\
\hline
\end{tabular}

the past the most. An online reader of De Morgen would have encountered the past in about $43 \%$ of the virus-related articles; in the earliest stages of coverage this would even have been more than $65 \%$.

\section{The Historical Cases and Examples Cited}

The Flemish media relied on a wide range of different historical cases and examples, illustrating how far-reaching and varied the use of the past has been at the beginning of the Corona-crisis. Despite the numerous individual references that needed to be analysed, two elements are readily apparent: the three Flemish news outlets considered the SARs-epidemic highly relevant, until it suddenly lost that relevance, and, with sARs gone, almost anything in history could turn into a point of reference.

As an important starting point, in total 294 of the 1258 virus-related articles mentioned one or more historical elements. In those 294 articles, 454 individual historical elements were cited, with, for example, two mentions of Spanish Flu in one article being counted as one element, and two mentions of Spanish Flu in two different articles as two. For the entire period and for all outlets, this implies that each article that referenced the past mentioned 1,54 different historical elements on average. Both VRT NWs and De Morgen show an upward line - their articles contained greater differing historical elements in February and March than in January. In contrast, De Standaard decreased the amount of different historical cases per article in the same period. Comparable to above, De Morgen also offered the most overall variation in elements cited: on average it cited 1,65 different historical cases per article.

Within this set of 454 historical elements, medical history was clearly dominant. In total twenty-four different past epidemics or disease outbreaks were referenced across the three media outlets. The earliest case was a second cen- 
TABLE 3 Number of historical cases, per article containing historical references

\begin{tabular}{lcccc}
\hline & $\mathbf{1} / \mathbf{1}-\mathbf{3 1} / \mathbf{1}$ & $\mathbf{1} / \mathbf{2}-\mathbf{2 9} / \mathbf{2}$ & $\mathbf{1} / \mathbf{3}-\mathbf{1 3} / \mathbf{3}$ & Total \\
\hline VRT NWS & 1,35 & 1,48 & 1,46 & 1,44 \\
De Standaard & 1,77 & 1,38 & 1,33 & 1,44 \\
De Morgen & 1,56 & 1,76 & 1,60 & 1,65 \\
Total & 1,59 & 1,51 & 1,44 & 1,54 \\
\hline
\end{tabular}

tury smallpox-epidemic; the most recent a 2019 swine flu outbreak. If the 19181919 Spanish Flu is taken as the dividing line between pre-modern and modern epidemics, only seven of the twenty-four cases can be considered pre-modern, or about $6,1 \%$ of the total amount of epidemics cited.

Some historical elements lost relevance in the course of the January-February-March period, others showed a clear increase in importance for Flemish media. The biggest 'loser' in this regard was the earlier mentioned 2002-2003 SARS epidemic, which became much less cited once media and commentators realized that the COVID-19 pandemic would turn out worse than the earlier SARS-outbreak. Particularly the death toll of CoviD-19 proved important in this respect - once the new Corona virus had caused more casualties than SARs, the 2002-2003 epidemic lost much of its relevance for Flemish media. The same applied to past outbreaks of MERs, Ebola, and Zika—but strangely enough not the 2004 Avian Flu or the 2009 Mexican Flu, both of which can hardly be considered equal outbreaks to the on-going pandemic. One possible explanation for the latter's popularity is that the expert researcher most often cited, Marc Van Ranst, earned his nickname 'the flu commissioner' during the 2009 epidemic, rendering it a well-known point of reference for the Flemish population.

Amongst the 'winners' of the escalating crisis were, unsurprisingly, much worse epidemics than SARS. These included the 14th century Plague, the 19181919 Spanish Flu, and HIV/AIDS, as their death tolls seemed to become more relevant from early February onwards. Effectively, in order to further fill the gap left by SARs, the journalists and experts of VRT NWS, De Standaard, and De Morgen went on a search for other historical elements that could offer guidance. The most significant percentage point increase could be noticed for the 'non-disease related' category, which went from $7,5 \%$ in January to $39,4 \%$ in March. Likewise, the 2008 financial crisis also became a point of reference from mid-February onwards, following growing economic concerns as the health crisis also became a production and demand crisis. In January, the 2008 eco- 
TABLE 4 Number of historical elements, as a percentage of the total historical cases referenced in that period (only elements with more than a $1 \%$ overall reference rate are listed)

Total $1 / 1-31 / 1 \quad$ Total $1 / 2-29 / 2 \quad \operatorname{Total}_{1 / 3}-13 / 3 \quad$ Total $1 / 1-13 / 3$

\begin{tabular}{lcrrr}
\hline 14th century Plague & - & $3,8 \%$ & $2,6 \%$ & $2,4 \%$ \\
$1918-1919$ Spanish Flu & $2,8 \%$ & $5,5 \%$ & $5,2 \%$ & $4,6 \%$ \\
1980's AIDS & - & $2,2 \%$ & $0,6 \%$ & $1,1 \%$ \\
$2002-2003$ SARS & $53,3 \%$ & $24,2 \%$ & $18,1 \%$ & $30,6 \%$ \\
$2004 \mathrm{H}_{5} \mathrm{~N}_{1} /$ Avian Flu & $1,9 \%$ & $2,7 \%$ & $2,6 \%$ & $2,4 \%$ \\
2008 Financial crisis & - & $6,6 \%$ & $\mathbf{1 5 , 5} \%$ & $7,9 \%$ \\
$2009 \mathrm{H} 1 \mathrm{~N} 1 /$ Mexican Flu & $3,7 \%$ & $8,2 \%$ & $6,5 \%$ & $6,4 \%$ \\
$2012 \mathrm{MERS}$ & $12,1 \%$ & $2,2 \%$ & $1,9 \%$ & $4,4 \%$ \\
2013 Ebola & $10,3 \%$ & $6,6 \%$ & $3,2 \%$ & $6,2 \%$ \\
2015 ZIKA & $4,7 \%$ & $2,2 \%$ & $0,6 \%$ & $2 \%$ \\
Non-disease related & $7,5 \%$ & $30,8 \%$ & $39,4 \%$ & $\mathbf{2 7 , 5} \%$
\end{tabular}

nomic meltdown was not mentioned once, while in early March it occupied $15 \%$ of all historical references.

Effectively, the historical frame deployed in the media did not exist of past diseases alone. 161 cited elements were non-medical in nature $(35,5 \%)$, with the most important one being the aforementioned 2008 financial crisis. Absolutely noteworthy is the staggering variety of historical elements in the 'non-disease related' category. It includes general and vague references such as 'for centuries' or 'since about the last decade', but also highly specific elements. To mention but a few: the Silk Roads; 18th century medical technology; 19th century racism and geopolitics; World War I; World War II; the founding of People's Republic of China; the 1970's oil crisis; the Iran hostage crisis; the Chernobyl disaster; the 1987 stock market crash; the 1991 Gulf War; 9/11; the 2015-2016 terror attacks in France and Belgium; and the 2016 Brexit-referendum all featured in one or more Corona-related articles.

This is only a fraction of the total list and displays only the more common or readily understandable historical cases. The longer list includes elements that at first sight appear strange, such as the Eighty Years War, the 1923 Tokyo earthquake, the 2010 development of the Boeing Dreamliner; the Eruption of the Eyjafjallajökull volcano, the 2011 Anders Breivik attack, and the Belgian team selection for the 2018 World Cup Football. As could be expected, the Holocaust and Nazi-propaganda were also mentioned in the Flemish Corona- 
related coverage. This staggering variety illustrates how after the breakdown of the SARs-based explanations, almost anything in history could be used to offer clarification or even guidance. From February onwards, history truly became a randomized 'grab-bag' whereby extremely different historical elements were considered valuable for understanding the crisis.

\section{Historical Reasoning about coviD-19, at a Glance}

If one looks at the historical reasoning of the three media outlets (meaning how they deployed the aforementioned historical cases in a wider argument about CoviD-19), it first and foremost needs to be acknowledged that much more research is needed. The above-mentioned variety in historical cases was almost matched by the variety in types of historical reasoning, which included, amongst others, history-based predictions about the future, using the past as a moral call to action, and several different explanatory analogies. Discussing all of these would lead this article too far, but some general observations per news outlet can be provided. Overall, the following section reinforces the abovementioned argument that 2002-2003 SARS epidemic was replaced by a much more varied historical frame of reference, adding that the comparison with SARS primarily served a reassuring purpose.

Starting with VRT NWS, the early historical references in its coverage were indeed intended to reassure the public. VRT NWs frequently cited experts as saying that the new outbreak was much less serious than the SARS-epidemic, adding that Flemish citizens should not worry. Moreover, the Chinese response was also praised as being much better than in 2002-2003, especially with regard to its global communication and cooperation. The analogy also carried weight in the economic sphere, as one VRT NWS article mentioned that entrepreneurs had a "déjà-vu feeling" to sARs, which was considered a relatively digestible historical economic crisis. ${ }^{11}$ However, the economic experts were also the first to note in VRT NWS coverage that this disease could have worse outcomes than SARs, simply because China's current global economic weight exceeds that of eighteen years ago.

On 8 February, VRT Nws published two articles mentioning the breakdown of the SARS-analogy in terms of amount of deaths, leading to an analytical article on 9 February that explained the background to the SARs-outbreak but also

11 P. Lambert, "Coronavirus besmet ook de Chinese economie: 'Veel beleggers hebben een déjà-vu-gevoel." VRT NWs, January 28, 2020, https://www.vrt.be/vrtnws/nl/2020/o1/28/ coronavirus-ook-schadelijk-voor-economie/. 
referenced the death tolls of the Spanish Flu, the Black Death, and several other deadly epidemics. ${ }^{12}$ More extensive history-based analytical pieces followed on 14 and 27 February, both of which were based on interviews with a medical historian. ${ }^{13}$ Despite the latter text carrying the rather alarmist title "History seems to repeat itself: in the Middle Ages, the plague also entered Europe through Italy", for most of February VRT NWS still used history to offer reassurances with regard to the disease itself. In late February and early March VRT NWS abandoned most of its analogies with medical history, except for one article on 10 March, which offered comparisons with several other recent disease outbreaks such as Zika, Ebola, and the Mexican Flu. ${ }^{14}$

Similarly, at the very beginning of the pandemic De Standaard also offered reassurances. The newspaper likewise cited experts referencing 2002-2003 as a much worse outbreak and highlighted the better response from the Chinese government. In mid-January this still included the field of economics, with one reassuring title being "For the Stock Markets, Corona is not yet SARs". 15 The main difference with VRT NWS at this early stage of reporting was that De Standaard offered much more background information on China, regularly highlighting the Chinese response to SARS in 2002-2003. However, by the end of January De Standaard started to report that some of the measures taken in China were unique from an historical standpoint, but this did not lead to a change in reassuring coverage. On the contrary, historical references to SARS continued to dominate, on several occasions citing experts who stated that preparations were much better than in 2002-2003 and minimizing the

12 J. De Greef, "Vijf nieuwe gevallen van coronavirus in Frankrijk, nu al elf in het totaal." VRT NWs, February 8, 2020, https://www.vrt.be/vrtnws/nl/2020/o2/o8/vijf-nieuwe-gevallen-va n-coronavirus-in-frankrijk-nu-al-elf-in/; L. De Wolf, "Wereldgezondheidsorganisatie wно: Aantal besmettingen met coronavirus stabiliseert." VRT NWS, February 8, 2020, https:// www.vrt.be/vrtnws/nl/2020/o2/o8/wereldgezondheidsorganisatie-who-aantal-besmetti ngen-met-corona/; J. De Greef, "Coronavirus nu officieel dodelijker dan sARs-uitbraak." VRT NWs, February 9, 202O, https://www.vrt.be/vrtnws/nl/2020/o2/og/coronvirus-nu-offi cieel-dodelijker-dan-sars-uitbraak/.

13 J. Vandervelden, "Precies 100 jaar geleden verdween de vernietigende Spaanse griep spontaan. Wat met het coronavirus?" VRT NWS, February 14, 2020, https://www.vrt.be/vrtnws/ nl/2020/o2/14/precies-10o-jaar-geleden-verdween-de-vernietigende-spaanse-griep/;

J. Vandervelden, "De geschiedenis lijkt zich te herhalen: in de middeleeuwen kwam ook de pest via Italië Europa binnen." VRT NWS, February 28, 2020, https://www.vrt.be/vrtnws/ $\mathrm{nl} / 2020 / 02 / 27 /$ hoe-ook-de-pest-via-italie-europa-binnendrong/.

14 F. Meijer, "Check: Besmetting met het nieuwe coronavirus is in Vlaanderen nog altijd lager dan veel andere infectieziekten." VRT NWS, March 10, 2020, https://www.vrt.be/vrtnws/nl/ 2020/o2/o5/check-coronavirus/.

15 S. Decock, "Corona is voor beurs nog geen sars." De Standaard, January 22, 2020, https:// www.standaard.be/cnt/dmf20200121_0481562o. 
chance of a SARs-like outbreak. Interestingly, the first major warning about covid-19 was included in a column by the historian Niall Ferguson, one of the protagonists in the field of applied history, who criticized the reassuring tone of many reporters yet remained himself relatively vague about the expected future. ${ }^{16}$

In early February, the historical references of De Standaard continued to focus on SARS and the Chinese response to viral outbreaks. This ended around 10 February, with the greater death toll of COVID-19 again being the determining factor. The historical focus shifted to the declaration of an official pandemic by the wHO, in particular to how unique such a statement would be and whether or not it would be the right step to take, given past precedents. The economic impact also mattered more in late February, with several 'worst performance since X'-articles appearing in De Standaard's coverage. The amount of historybased reassurances diminished to almost zero, with the first really alarmist citation appearing on 27 February: one researcher was quoted as saying "a scenario like the Spanish Flu in 1919 is possible". ${ }^{17}$

Several articles in De Standaard also used history as their basis for commentary. On 13 and 29 February the newspaper devoted two larger pieces to the societal impact of diseases, showing how in the past marginalized groups were frequently blamed for an outbreak. ${ }^{18}$ Both texts used history to offer a stark warning for the future: beware of how politicians and demagogues will exploit the fear of this new deadly disease. This history-based advice also extended to the economic coverage of the newspaper, as one commentator used previous cases of stock market 'Black Mondays' to convince investors that a calm approach would suit them best. ${ }^{19}$ On 2 March two academic historians also published an op-ed criticizing the comparisons with the Black Death, adding that a potentially better analogy would be the Eighteenth-century Cattle Plague

16 N. Ferguson, "Het dodelijkste virus is niet corona, maar de laksheid." De Standaard, February 3, 2020, https://www.standaard.be/cnt/dmf20200202_04831884. This is a Dutch copy of professor Ferguson's column "The deadliest virus we face is complacency." The Sunday Times, February 2, 2020, https://www.thetimes.co.uk/article/the-deadliest-virus-we-face -is-complacency-wsp7xdr7s.

17 P. Vantyghem and S. Grymonprez, “'Ik durf nu al minder buiten te komen.'” De Standaard, February 27, 2020, https://www.standaard.be/cnt/dmf20200226_04866585.

18 T. Beeckman, "Een vlaag van walging." De Standaard, February 13, 2020, https://www .standaard.be/cnt/dmf2O200212_04846149; M. Reynebeau, "Elke epidemie heeft haar zondebok nodig.", De Standaard, February 29, 2020, https://www.standaard.be/cnt/dmf2O2Oo 228_0486966o.

19 J. Reyns, "Eerste hulp na beurscrash." De Standaard, March 12, 2020, https://www.standaard .be/cnt/dmf20200311_04886043. 
or Rinderpest, which offered an example of early "biopolitics" and held a warning against unnecessary state intervention. ${ }^{20}$

Interestingly, and in contrast to both VRT NwS and De Standaard, De Morgen was much less inclined to use historical references as reassurances. The death toll of 2002-2003 SARS was almost uniformly highlighted, and one article was titled "Are we witnessing the birth of a new killer?". ${ }^{21}$ Likewise, De Morgen cited experts as saying that this new virus could become as lethal as SARS, although reassuring comparisons were not entirely absent. By late January these reassurances actually increased, with De Morgen stressing the better response from China and the biological differences between SARS and the new virus. On 27 January, one long article compared the 2002-2003 Chinese response to the current one, stressing the different political contexts. ${ }^{22}$ Still, in line with its more concerned approach, De Morgen was the first to mention that this outbreak was already worse than that of sARs, based on the infection rate on 28 January. ${ }^{23}$ On 7 February, a journalist from De Morgen took the Spanish Flu as the starting point for an interview with a virologist, asking the expert to sketch a hypothetical contemporary scenario based on this historical pandemic. ${ }^{24}$ In another interview a similar hypothetical question was asked, with in both cases the answer being that our medical knowledge today makes a scenario comparable to $1918-1919$ highly unlikely. ${ }^{25}$

Effectively, De Morgen included several types of historical reasoning that could not be found in the other two media, or at least not to the same degree

$20 \quad$ T. Soens and S. Geens, "Een staaltje biopolitiek?" De Standaard, March 2, 2020, https:// www.standaard.be/cnt/dmf2O200301_04871366.

21 M. Keulemans, "Zijn we getuige van de geboorte van een nieuwe killer? Chinese longziekte is een 'sars-achtig virus'." De Morgen, January 17, 2020, https://www.demorgen.be/nieuws/ zijn-we-getuige-van-de-geboorte-van-een-nieuwe-killer-chinese-longziekte-is-een-sarsachtig-virus b81aa207/.

22 M. Vlaskamp, “Van sARs naar corona: heeft China dan écht niks geleerd?" De Morgen, January 27, 2020, https://www.demorgen.be/nieuws/van-sars-naar-corona-heeft-china-dan -echt-niks-geleerd $\sim$ b3oeebfe/.

23 M. Keulemans, "Wuhan-virus begint sARs-proporties aan te nemen: 'Europa moet zich voorbereiden'." De Morgen, January 28, 2020, https://www.demorgen.be/nieuws/wuh an-virus-begint-sars-proporties-aan-te-nemen-europa-moet-zich-voorbereiden $\sim$ bdee 638 e/.

24 J. Denaeghel, "'Volgens mij is het coronavirus overal in Europa uitgezaaid', De Morgen, February 7, 2020, https://www.demorgen.be/tech-wetenschap/volgens-mij-is-het-corona virus-overal-in-europa-uitgezaaid be1394a2/.

25 J. De Ceulaer, “'Maatregelen zijn nu erger dan coronavirus zelf': vaccinatie-expert Pierre Van Damme (UA)." De Morgen, February 17, 2020, https://www.demorgen.be/nieuws/maat regelen-zijn-nu-erger-dan-coronavirus-zelf-vaccinatie-expert-pierre-van-damme-ua $\sim \mathrm{bc}$ $\mathrm{d}_{7} \mathrm{~d}_{4} \mathrm{~d}_{7} /$. 
or with the same prominence. On one side, De Morgen offered an interview with a stock market expert who explicitly mentioned that the sARS-comparison had thrown investors off guard-the reassurance that this epidemic would not be worse than 2002-2003 had made economists realize too late that this time would indeed be different, and in a major way. ${ }^{26}$ On the other side, $D e$ Morgen also published a column by a sports reporter with a history degree, who complained about the virus-hysteria (as he saw it), blaming it on the lack of experience of younger journalists and, perhaps, the "caring reflexes" of the growing number of female reporters. ${ }^{27}$ Similarly, De Morgen asked the opinion of a controversial Flemish politician, who stated "I refuse to give in to panic. We need to learn to live with nature again" before making a comparison with the, in his view, unpreventable Black Death. ${ }^{28}$ These three articles illustrate how the use of the past in De Morgen was extremely varied from early on and included more extreme, yet still history-influenced, points of view.

The most obvious conclusion from this analysis of the Corona-related coverage of VRT NWS, De Standaard, and De Morgen, is that Flemish media used a lot of history to explain COVID-19, but made a mistake in drawing reassuring conclusions based on the analogy with the 2002-2003 SARS epidemic. This conclusion is, however, also the most unfair. The three media had to rely on information provided by other sources, such as virologists and epidemiologists, who offered many of the sARs-based reassurances. In other words, the reliance on this analogy had not entirely been their own choice. Moreover, it is only in hindsight that the results of the comparison with sARs can be considered a mistake. Today we know that the COVID-19 pandemic is worse than SARs, but in January 2020 all scenarios were still possible, including one not too differ-

26 TTR, “Financieel expert Paul D'Hoore: 'Vrees voor recessie is terecht'." De Morgen, March 9, 2020, https://www.demorgen.be/nieuws/financieel-expert-paul-d-hoore-vrees-voor-rece ssie-is-terecht $\sim$ b29f $32 \mathrm{e} 4 /$.

27 H. Vandeweghe, "Handjes schudden was verboden, maar bij corners werden druppels groot en klein uitgewisseld." De Morgen, March 9, 2020, https://www.demorgen.be/menin gen/handjes-schudden-was-verboden-maar-bij-corners-werden-druppels-groot-en-klein -uitgewisseld bf $303383 /$.

28 M. De Decker, "Waren de forse maatregelen tegen het coronavirus noodzakelijk of niet? 'Vrouwen kunnen nog steeds een kus krijgen van mij'." De Morgen, March 13, 2020, https:// www.demorgen.be/nieuws/waren-de-forse-maatregelen-tegen-het-coronavirus-noodza kelijk-of-niet-vrouwen-kunnen-nog-steeds-een-kus-krijgen-van-mij b8cc5abf/. 
ent from 2002-2003. So, although mistakes were certainly made in comparing COVID-19 to the history of SARS, we should not judge too harshly about those who drew the analogies.

Nevertheless, this case-study holds a warning for anyone who wants to rely on the past in times of crisis. The statement of Guillaume Lachenal and Gaë$\tan$ Thomas that "history has no lessons" for coviD-19 might be (too) strongly put, but they are correct in observing that relying on historical analogies and comparisons can obscure vital information. ${ }^{29}$ As one economist observed in $D e$ Morgen, it was exactly by stressing the similarities between COVID-19 and SARS that the media, policymakers, and experts were shushed into early complacency. ${ }^{30}$ It even seems that many commentators did not rely on actual comparisons between past and present, but rather on the belief that past and present would have comparable outcomes. In January, at a point were little was known about the new disease, commentators already asserted that this time would be no worse than SARS. Additionally, when the media did start to report about the growing differences with 2002-2003, the general argument remained that the similarities still outweighed the differences. Only when the most important point of the analogy, the death toll of SARs, broke down, did commentators start to take the differences with history serious.

Finally, and as a related conclusion, the extreme variety in historical references that has emerged since February 2020 highlights how media and commentators are still actively searching for the best point of comparison. Whether it is epidemic X or Y, or even a non-medical past event, the demand for advice from history is currently very large. In this regard, applied historians can help news outlets in navigating this historical minefield, pointing out that every comparison comes with its own premises. Those premises should be proactively, not reactively, provided to media outlets, which means highlighting the risks already before journalists start asking questions about how the present could be like the past. Otherwise the danger remains that the further handling of the COVID-19 crisis will be influenced by equally problematic conclusions based on historical analogies. One potential risk is, for example, that media move from comparisons with SARs to the Spanish Flu and the plague. Illustrative in this sense are more recent articles claiming that the measures adopted by certain cities during the Spanish Flu reveal the most effective way for dealing with CovID-19, or statements that the current quarantine measures will work because they did so in the Middle Ages. ${ }^{31}$ Comparably, there exists a significant

29 Lachenal and Thomas, "Covid-19".

3 О TTR, "Financieel expert".

31 B. Debusschere, “'De middeleeuwse aanpak werkt': Marc Van Ranst over de draconische 
risk that comparisons with the financial crisis of 2008 will help to determine the handling of the upcoming economic fall-out of covid-19, even though most economists agree that they are not really comparable. As such, this article holds the warning that relying on the past might be a natural reflex for the media in times of crisis, but that acting on one analogy alone can turn into a costly mistake.

Italiaanse corona-maatregelen." De Morgen, March 9, 2020, https://www.demorgen.be/ nieuws/de-middeleeuwse-aanpak-werkt-marc-van-ranst-over-de-draconische-italiaanse -corona-maatregelen bff3c949c/; R. Mooijman, "Krachtig ingrijpen, snel herstel." De Standaard, March 28, 2020, https://www.standaard.be/cnt/dmf2O2O0327_049O4904. 